\title{
Oxygen uptake during mineralization of photosynthesized carbon from phytoplankton of the Barra Bonita Reservoir: a mesocosm study
}

\author{
Cunha-Santino, MB. ${ }^{\mathrm{a}}$, Gouvêa, SP. ${ }^{\mathrm{b}}$, Bianchini Jr. I., ${ }^{\mathrm{c} *}$ and Vieira, AAH. ${ }^{\mathrm{d}}$ \\ ${ }^{a}$ Universidade Federal de São Carlos - UFSCar, \\ Rodovia Washington Luis, Km 235, CEP 13565-905, CP 676, São Carlos, SP, Brazil \\ ${ }^{b}$ Departamento de Biologia, Campus Miguel Petroni, Centro Universitário Central Paulista - UNICEP, \\ Rua Miguel Petroni, 5111, CEP 13563-470, São Carlos, SP, Brazil \\ 'Departamento de Hidrobiologia, Universidade Federal de São Carlos - UFSCar, \\ Rodovia Washington Luis, Km 235, CEP 13565-905, CP 676, São Carlos, SP, Brazil

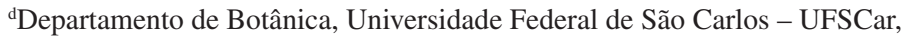 \\ Rodovia Washington Luis, Km 235, CEP 13565-905, CP 676, São Carlos, SP, Brazil \\ *e-mail: irineu@power.ufscar.br \\ Received July 24, 2006 - Accepted September 18, 2006 - Distributed February 29, 2008
}

(With 2 figures)

\begin{abstract}
This study aimed to discuss and describe the oxygen consumption during aerobic mineralization of organic products (cells and excretion products) from five unialgal cultures: Cryptomonas sp., Microcystis aeruginosa, Anabaena spiroides, Thalassiosira sp. and Aulacoseira granulata. These species were isolated from Barra Bonita reservoir $\left(22^{\circ} 29^{\prime} \mathrm{S}\right.$ and $\left.48^{\circ} 34^{\prime} \mathrm{W}\right)$ and cultivated in the laboratory. From each culture, two decomposition chambers were prepared; each chamber contained about $130 \mathrm{mg} . \mathrm{L}^{-1}$ of carbon from water samples of the reservoir. The chambers were aerated and incubated in the dark at $20.0^{\circ} \mathrm{C}$. The concentration of dissolved oxygen, $\mathrm{pH}$ values and electrical conductivity of the solutions were determined during a period of 10 days. The results indicated increases in oxygen consumption for all the solutions studied and also for electrical conductivity. The $\mathrm{pH}$ values presented a decreasing tendency throughout the experiment. Oxygen consumption varied from 43 (Aulacoseira granulata chamber) to $345 \mathrm{mg} \mathrm{O}_{2} \mathrm{~g}^{-1} \mathrm{C}$ (Anabaena spiroides chamber). Decrease in $\mathrm{pH}$ values was probably due to increase in $\mathrm{CO}_{2}$ concentration from microbial respiration. Increase in electrical conductivity might be due to the liberation of ions during decomposition. The results demonstrate the potentiality of the studied genera in influencing oxygen availability followed by a die-off event. It also indicates the possibility of changing of the electrical conductivity and $\mathrm{pH}$ values in the water column due the aerobic algae mineralization.
\end{abstract}

Keywords: aerobic mineralization, algae, Barra Bonita Reservoir (Barra Bonita, SP, Brazil), oxygen uptake.

\section{Consumo de oxigênio da mineralização de carbono fotossintetizado de fitoplâncton do Reservatório de Barra Bonita: um estudo em mesocosmo}

\section{Resumo}

Este estudo teve por objetivo descrever e discutir aspectos do consumo de oxigênio decorrente da mineralização aeróbia de células e produtos de excreção provenientes de cinco culturas de algas: Cryptomonas sp., Microcystis aeruginosa, Anabaena spiroides, Thalassiosira sp. e Aulacoseira granulata. As algas foram isoladas do reservatório de Barra Bonita (22 $29^{\prime} \mathrm{S}$ e $48^{\circ} 34^{\prime} \mathrm{W}$ ) e cultivadas em laboratório. Para cada cultura, foram preparadas duas câmaras de mineralização; cada garrafa conteve, em base de carbono, cerca de $130 \mathrm{mg} . \mathrm{L}^{-1} \mathrm{em}$ amostras de água do reservatório. As câmaras foram aeradas e incubadas no escuro a $20^{\circ} \mathrm{C}$. Durante um período de 10 dias, foram determinadas as concentrações de oxigênio dissolvido, $\mathrm{pH}$ e condutividade elétrica das misturas. Os resultados indicaram incrementos nos consumos de oxigênio e de condutividade elétrica e decréscimos nos valores de $\mathrm{pH}$. $\mathrm{O}$ consumo de oxigênio variou de 43 (experimento com Aulacoseira granulata) a $345 \mathrm{mg} \mathrm{O}_{2} \mathrm{~g}^{-1} \mathrm{C}$ (experimento com Anabaena spiroides). Os aumentos dos valores de condutividade elétrica provavelmente decorreram da liberação de íons durante a decomposição. Para o pH, a diminuição dos valores foi provavelmente resultante do incremento das concentrações de $\mathrm{CO}_{2}$ provenientes da respiração dos microrganismos. Os resultados sugeriram para a represa de Barra Bonita, a possibilidade de incremento das demandas de oxigênio em função da degradação dos gêneros 
selecionados. Visto que esse reservatório é eutrófico, os resultados indicam também a possibilidade de alterações da condutividade elétrica da água e do pH devido à mineralização aeróbia de algas.

Palavras-chave: consumo de oxigênio, mineralização aeróbia, algas, reservatório de Barra Bonita (Barra Bonita, SP, Brasil).

\section{Introduction}

Phytoplankton is considered an important primary producer in many aquatic systems. Their photosynthetic products are one of the sources of organic material content in the water column of aquatic ecosystems. The degradation of photosynthetically fixed organic carbon in oceans, lakes and reservoirs is one of the most important transformations in the global carbon cycle (Chen and Wangersky, 1996; Daniels et al., 2006).

According to Straškraba and Tundisi (2000), in the Barra Bonita reservoir the nutrient inputs are due to anthropogenic processes related to agriculture, cattle breeding, industrial and domestic sewage. Some consequences are eutrophication with intensive growth of aquatic macrophytes and cyanobacteria blooms (Microcystis sp. in summer and Anabaena sp. during tropical winter). Decomposition of algae is considered to be an important process in the regeneration of organic and inorganic compounds in aquatic ecosystems (Brouwer, 1996). The extent to which the algal biomass will be decomposed and the factors that affect this process are of concern for the effect of algae decomposition on the oxygen budget of freshwater ecosystems like reservoirs and lakes. In eutrophic ecosystems the clarification of algal decay kinetics will provide information necessary to understand and avoid such serious consequences of algal decomposition that interfere in the global oxygen budget of the system.

The extent and rate of organic matter degradation throughout microbial communities metabolism are affected by environmental factors such as redox conditions (Otsuki and Hanya, 1972a, b; Pacobahyba et al., 2004), temperature (White et al., 1991), nutrient content of algal cells, decomposer density and the resistance of algae to microbial decomposition (Gunnison and Alexander, 1975). In this context, few data about algae decomposition are available, making discussion and comparison a difficult task. Considering that the phytoplankton biomass content in the Barra Bonita reservoir is increasing due to eutrophication (Barbosa et al., 1999), and the importance of phytoplankton in decomposition events, this study aimed at the description and discussion of oxygen uptake kinetics from decomposition experiments of five phytoplankton species from Barra Bonita Reservoir (São Paulo, Brazil).

\section{Materials and Methods}

\subsection{Description of the area}

Barra Bonita Reservoir ( $22^{\circ} 29^{\prime} \mathrm{S}$ and $48^{\circ} 34^{\prime} \mathrm{W}$ ) is an artificial water system constructed in 1963 , located between Barra Bonita and Igaraçu cities. Its morphometry is described by Straškraba and Tundisi (2000). The maximum depth is $25 \mathrm{~m}$. Its hydrographic basin area (30\% forests, $50 \%$ intensive agriculture, $20 \%$ pasture) comprises $324.84 \mathrm{~km}^{2}$. The reservoir has a volume of $33.6 \times 10^{6} \mathrm{~m}^{3}$ and a theoretical retention time of 90 days. The anthropogenic pressure on Barra Bonita Reservoir affects the water quality of this system, characterized as eutrophic (Henry et al., 1985; Tundisi and MatsumuraTundisi, 1990).

\subsection{Species selection}

The choice of the species for this study was based on their importance in the reservoir. The cyanobacteria Microcystis aeruginosa Kützing 1846 and Anabaena spiroides Klebahn 1895 and the diatom Aulacoseira granulata (Ehrenberg) Simonsen 1979 represent the dominant species related to biomass though Thalassiosira sp. and Cryptomonas sp. are not biomass predominant in the reservoir; they were also selected for their importance in nutrient cycling (Dellamano-Oliveira and Vieira, submitted).

\subsection{Isolation and cultivation of algal cells}

Methods for algal isolation as described in Vieira (1977) were applied for the isolation of the species, which are maintained in the freshwater phytoplankton culture collection at the Botany Department, Universidade Federal de São Carlos (WDCM 835). The culture media used were ASM-1 (Gorham et al., 1964) for the cyanobacteria species and WC (Guillard and Lorenzen, 1972) for other species. Algae cultures were grown in glass carboys of $4 \mathrm{~L}$ capacity, with $3 \mathrm{~L}$ of medium, using algae inoculum at the exponential phase. Culture conditions were constant temperature $\left(20-22{ }^{\circ} \mathrm{C}\right), \mathrm{pH}(6.8-7.0)$, irradiance $\left(265 \mu \mathrm{mol} . \mathrm{m}^{-2} / \mathrm{s}\right)$ supplied by day-light fluorescent tubes of $40 \mathrm{~W}$ with a light-dark cycle of $12: 12$ hours and aeration by gently bubbling of filtered and moist air.

\subsection{Experimental design}

For each alga, two decomposition chambers were prepared with the unialgal cultures and glass wool filtered reservoir water for removal of gross material (initial concentration in carbon basis ca. $130 \mathrm{mg} . \mathrm{L}^{-1}$ ). The algae cultures were harvested at the beginning of the stationary phase. The chambers were incubated in the dark to avoid primary production, at $20.05 \pm 0.99{ }^{\circ} \mathrm{C}$. Aerobic conditions (dissolved oxygen near saturation) were maintained by 1 hour oxygenation during every sampling day. After the oxygenation, the DO was meas- 
ured by an ODmeter (YSI model 58). At DO concentrations reaching $2.0 \mathrm{mg} . \mathrm{L}^{-1}$, the solutions where oxygenated again during the experiments, up to the saturation value correspondent to the temperature of incubation. The oxygen uptake was estimated periodically during 10 days. The $\mathrm{pH}$ and the electrical conductivity (EC) were determined potentiometrically (Digimed DMPH-2 and Digimed DM3). All the values of OD, $\mathrm{pH}$ and electrical conductivity were blank-corrected with measures using the reservoir water.

\subsection{Oxygen uptake equations}

The consumption of oxygen in the experiments was considered directly related with the oxidation of the organic resources present, and that this process can be represented by kinetic models (Characklis, 1990; Henze et al., 1997; Cunha-Santino and Bianchini Jr., 2002). The temporal variation of the evolved oxygen was fitted to a first-order kinetics model using a non-linear method, the Levenberg-Marquardt iterative algorithm, according to Press et al. (1993). From these considerations, it is possible to describe the variation in the DO decay (Equation 1) according to the following equations:

$O C=O C_{\max }\left(1-e^{-k_{D} t}\right)$

where: $\mathrm{OC}=$ accumulated value of consumed oxygen (mg.L $\left.\mathrm{L}^{-1}\right) ; \mathrm{OC}_{\max }=$ maximum amount of consumed oxygen $\left(\mathrm{mg} . \mathrm{L}^{-1}\right) ; \mathrm{k}_{\mathrm{D}}=$ deoxygenation rate constant (per day); and $\mathrm{t}=$ time (day).

The half-time $\left(\mathrm{t}_{1 / 2}\right)$ of deoxygenation derived from aerobic decomposition of algae was calculated according to the Equation 2.

$t_{1 / 2}=\frac{\ln 0.5}{-k_{D}}$

The effects of oxidation from the flasks with algae were corrected by subtraction of OC values from the control flasks. The OC, $\mathrm{pH}$ and EC data were statistically analyzed using analysis of variance (Kruskal-Wallis) followed by Dunn's test in order to verify for significant differences among treatments $(\mathrm{p}<0.05)$.

\section{Results}

The kinetics of oxygen uptake during the aerobic mineralization of Cryptomonas sp., Microcystis aeruginosa, Anabaena spiroides, Thalasiosira sp. and Aulacoseira granulata are shown in Figure 1. From the kinetic fittings (Table 1), the mineralization of algae had the oxygen consumption $\left(\mathrm{OC}_{\max }\right)$ ranging from $43 \mathrm{mg} \cdot \mathrm{g}^{-1} \mathrm{C}$ (Aulacoseira granulata) to $345 \mathrm{mg} \cdot \mathrm{g}^{-1} \mathrm{C}$ (Anabaena spiroides). The values of the deoxygenation rate constant $\left(\mathrm{k}_{\mathrm{D}}\right)$ ranged from 0.0545 to $0.3785 /$ day and their corresponding $\mathrm{t}_{1 / 2}$ (half-time) varied between 2 to 13 days (Table 1). The highest $\mathrm{k}_{\mathrm{d}}$ was obtained with the mineralization of Aulacoseira granulata (0.3785/day), followed by Microcystis aeruginosa, Cryptomonas sp., Thalassiosira sp. and Anabaena spiroides (0.2099; $0.1911 ; 0.1575$ and $0.0545 /$ day, respectively). The de- termination coefficients $\left(\mathrm{r}^{2}\right)$ for the kinetic fitting varied from 0.91 to 0.99 . Using the kinetics of oxygen consumption, the Kruskal-Wallis analysis resulted in significant differences among the values for Cryptomonas sp. and Microcystis aeruginosa $(\mathrm{p}<0.01)$ and Aulacoseira granulata ( $\mathrm{p}<0.001)$; Microcystis aeruginosa results were statistically distinct of those from Anabaena spiroides $(\mathrm{p}<0.001)$ and Thalassiosira $\mathrm{sp} .(\mathrm{p}<0.001)$.

The $\mathrm{pH}$ values of incubations varied from 6.81 in the decomposing media of Aulacoseira granulata to 7.41 for incubation with Cryptomonas sp. (Figure 2). $\mathrm{pH}$ values tended to decrease, except for Thalassiosira sp., which presented a tiny decaying variation. The statistical analyses pointed to differences in the temporal variation of $\mathrm{pH}$ of the Aulacoseira granulata chambers in relation to Cryptomonas sp. $(\mathrm{p}<0.001)$, Microcystis aeruginosa $(\mathrm{p}<0.05)$ and Thalassiosira $\mathrm{sp} .(\mathrm{p}<0.01)$ experiments. Cryptomonas sp. experiments also differed in $\mathrm{pH}$ ( $\mathrm{p}<0.05)$ from the Anabaena spiroides experiments.

The minimum and maximum values for electrical conductivity (EC) among the incubations were 48.3 and $59.1 \mu{\mathrm{S} . \mathrm{cm}^{-1}}^{-1}$ Figure 2). The incubations with Microcystis aeruginosa and Anabaena spiroides showed increases in EC during degradation, while with Aulacoseira granulata, Cryptomonas sp. and Thalassiosira sp., an attenuated EC decrease was shown. Differences in the temporal variation of $\mathrm{CE}$ among the incubations with Microcystis aeruginosa and Aulacoseira granulata ( $\mathrm{p}$ $<0.05)$, Cryptomonas sp. $(\mathrm{p}<0.001)$ and Thalassiosira sp. $(\mathrm{p}<0.001)$ were revealed by statistical analyses. Values of CE for Anabaena spiroides incubations differed to the CE of Cryptomonas sp. $(\mathrm{p}<0.01)$ and Thalassiosira sp. $(\mathrm{p}<0.001)$ incubations.

\section{Discussion}

Several studies have demonstrated a sudden die-off of phytoplankton blooms in aquatic ecosystems (Barica, 1974; Lee and Lee, 1995). As a primary consequence of this event, fast oxygen depletion occurs and ammonia increases in concentration. The total amount of $\mathrm{OC}_{\max }$, obtained in the dark, is usually employed as a measure of total heterotrophic activity in samples of lake water and sediments, and it is therefore reasonable to use $\mathrm{OC}_{\max }$ to follow the process of a microbial reaction in aerobic environments (Characklis, 1990). The long-term BOD tests are the practical procedure that expresses this variable (Cunha-Santino and Bianchini Jr., 2003a). The extent of temporal evolution of the oxygen consumption describes the metabolic activity of the microorganisms involved in the mineralization process and the recalcitrance of the structural compounds of phytoplanktonic cells.

Considering the high determination coefficients $\left(\mathrm{r}^{2}\right.$ : from 0.91 to 0.99 ) obtained on the fittings of the kinetic model (Figure 1) to the experimental results (Table 1), the proposed model (Equation 1) represents the kinetics of oxygen uptake. The oxygen uptake observed during algae decay presented similarities with that observed in the mineralization process of aquatic macrophytes 

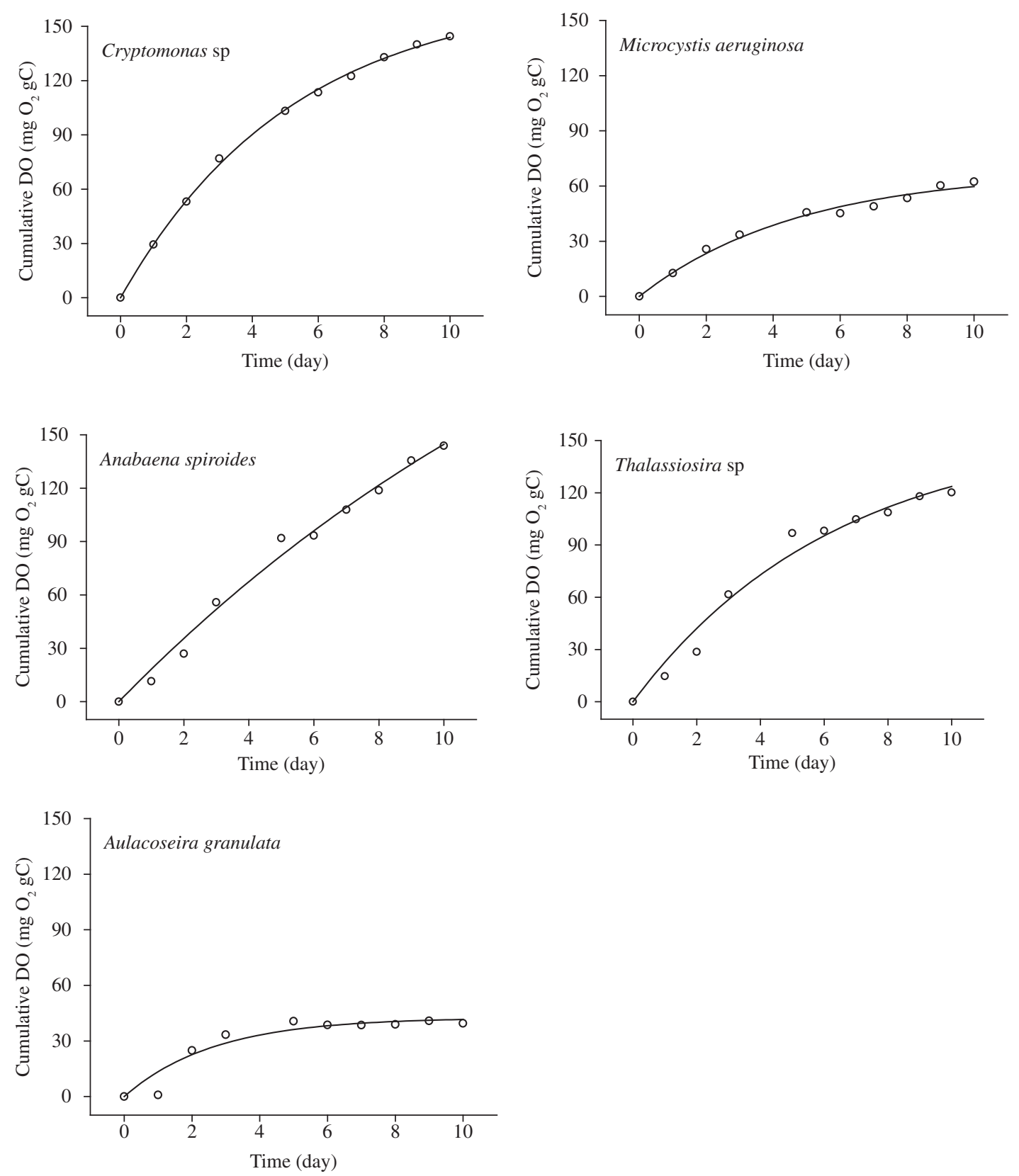

Figure 1. Oxygen consumption during the aerobic mineralization of Cryptomonas sp, Microcystis aeruginosa, Anabaena spiroides, Thalassiosira sp and Aulacoseira granulata.

(Bianchini Jr. et al., 2006). The mineralization process tended to have an accentuated consumption of the dissolved oxygen in the beginning of the process, followed by a period tending to stabilization of oxygen consumption. After this phase, the decay was less intense, probably due to i) the remaining refractory compound derived from the cellular walls, which are composed of cellulose impregnated with pectin (Brook, 1981) that gives to the algae detritus more resistance to bacterial attacks (refractory fraction) and ii) the utilization of the nutrients in the first stage, limiting the growth of microorganisms and turning the decomposition a slow process. Considering that the algal detritus is a heterogeneous source of organic matter presenting labile and refractory compounds, the oxygen uptake was probably related to the labile fractions. Hence differences in oxygen consumption were related to the chemical composition of the plant material, presenting a positive relation with higher concentrations of nitrogen and lower content of cellulose (Almazan and Boyd, 1978).

Experiments of the aerobic decomposition of cells of Staurastrum iversenii under different temperatures 
Table 1. Parameterization of the kinetic model during Cryptomonas sp, Microcystis aeruginosa, Anabaena spiroides, Thalassiosira sp and Aulacoseira granulata mineralization process: $\mathrm{OC}_{\max }=$ oxygen consumption; $\mathrm{k}_{\mathrm{D}}=\mathrm{DO}$ consumption coefficient; $\mathrm{t}_{1 / 2}$ : DO consumption half-time; $\mathrm{r}^{2}=$ determination coefficient and error $=$ error referred to the kinetics fittings.

\begin{tabular}{lccccrr}
\hline \multicolumn{1}{c}{ Specie/Genera } & $\begin{array}{c}\mathbf{O C}_{\mathbf{m a x}} \\
\left(\mathbf{m g . g ~ C}^{\mathbf{1}}\right)\end{array}$ & Error & $\mathbf{K}_{\mathbf{D}}$ (per day) & Error & $\mathbf{t}_{\mathbf{1 / 2}}$ & $\mathbf{r}^{\mathbf{2}}$ \\
\hline Cryptomonas sp. & 169 & 3 & 0.1911 & 0.0075 & 4 & 0.99 \\
Microcystis aeruginosa & 68 & 4 & 0.2099 & 0.0291 & 3 & 0.98 \\
Anabaena spiroides & 345 & 112 & 0.0545 & 0.0220 & 13 & 0.99 \\
Thalassiosira sp. & 156 & 20 & 0.1575 & 0.0370 & 4 & 0.98 \\
Aulacoseira granulata & 43 & 4 & 0.3785 & 0.1086 & 2 & 0.91 \\
\hline
\end{tabular}
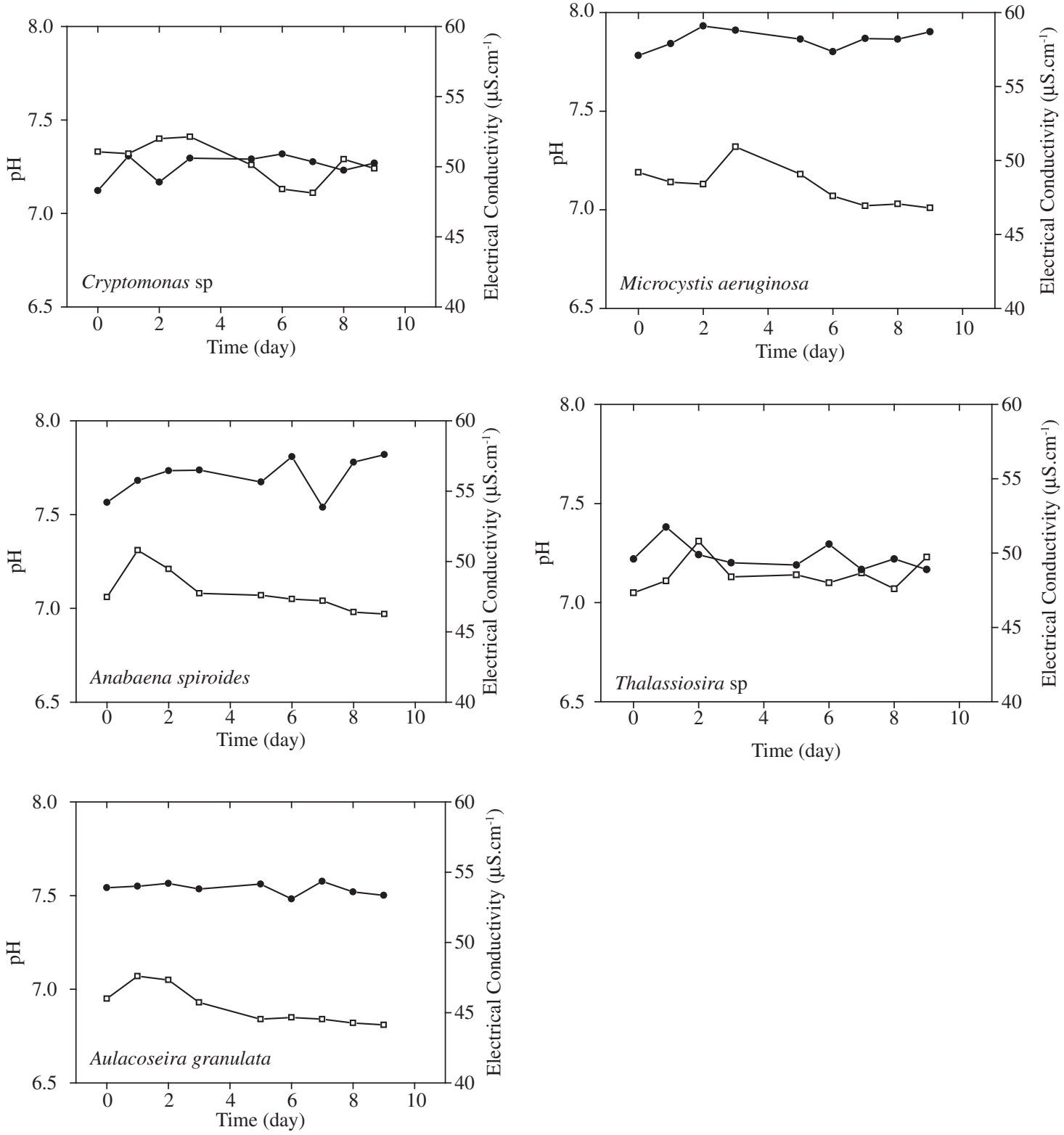

Figure 2. Temporal variation of $\mathrm{pH}$ and electrical conductivity values during the aerobic mineralization of the algae incubations: $\mathrm{pH}(\square)$ and electrical conductivity $(\bullet)$. 
presented differences in the values of $\mathrm{OC}_{\max }$ (Table 2). The decay verified in the incubation with glucose and water from Barra Bonita reservoir produced an $\mathrm{OC}_{\max }$ of 496 mg. $\mathrm{g}^{-1} \mathrm{C}$ (Panhota and Bianchini Jr., 2003). In comparison with glucose, the algae species used in the present experiment showed a low OC, indicating a greater refractability of the cell materials. Considering as $26 \%$ the average of phytoplankton carbon content (Platt and Irwin, 1973), an experiment of oxygen consumption with five species of algae (Almazan and Boyd, 1978) showed $\mathrm{OC}_{\max }$ varying from $106 \mathrm{mg} \cdot \mathrm{g}^{-1} \mathrm{C}$ (Euglena proxima) to $633 \mathrm{mg} \cdot \mathrm{g}^{-1} \mathrm{C}$ (Anabaena circinalis; Table 2).

Aerobic decomposition differs in the Barra Bonita Reservoir according to the type of algae predominating. This aquatic system presented its dissolved oxygen budget most affected by Aulacoseira granulata, followed by Microcystis aeruginosa, Thalassiosira sp., Cryptomonas sp. and Anabaena spiroides. Depending on the species, biomass and composition of a phytoplankton bloom, the oxygen demand during its die-off will regulate the oxygen availability in the water column. Species presenting higher content of recalcitrant material will contribute with benthic oxygen demand once that debris tends to accumulate on the sediment surface.

In our experiments, the values of the deoxygenation coefficients $\left(\mathrm{k}_{\mathrm{d}}: 0.055\right.$ to $0.379 /$ day) for the aerobic mineralization of algae presented great variations among the species studied. The oxygen uptake during the decomposition of Aulacoseira granulata was ca. 7 times faster than for Anabaena spiroides decomposition. According to Hartemink and O'Sullivan (2001), slow decomposition is mainly caused by high $\mathrm{C} / \mathrm{N}$ ratio. More organic cell surface favors the biofilm development, with a faster decomposition in these cases than on inorganic cell surface. Other organic substrates showed the following $\mathrm{k}_{\mathrm{d}}$ values: 0.39 /day (tannic acid, Cunha-Santino et al., 2002); 0.11/day (leaves), 0.52/ day (branches), 0.36/day (barks) and 0.11/day (litter;
Antonio et al., 1999); 0.016/day (glucose), 0.025/day (sucrose), 0.050/day (starch) and 0.048/day (lysine; Cunha-Santino and Bianchini Jr., 2003b).

Considering the microbial loop of the aquatic systems, the effect of the microbial decay on the aerobic regulation of the dissolved organic matter concentrations is directly related with the $\mathrm{k}_{\mathrm{D}}$. Mineralization processes presenting higher $\mathrm{k}_{\mathrm{D}}$ (i.e. short half- time) have a great potential for biodegradability. Due to the higher $\mathrm{k}_{\mathrm{D}}$, these fractions do not tend to accumulate in the ecosystem. In opposition, the fractions with lower $\mathrm{k}_{\mathrm{D}}$ probably remain unaffected for longer periods, and consequently, are present at the highest concentrations, tending to accumulate in sediments. Hence, the organic matter generated at Barra Bonita reservoir and its $\mathrm{k}_{\mathrm{D}}$ acts directly on the quality and quantity of the carbon cycle in this system. Another fact related to the potentiality of the biodegradability is the indigenous microbiota of the reservoir water. The adaptability of these organisms to the immobilization and mineralization will also affect the concentrations of the carbon compounds in the aquatic environment.

Owing to the algae chemical composition and their specific mineralization rates, the effects on acidification and release of ionic species in the water column are distinct among Aulacoseira granulata, Microcystis aeruginosa, Thalassiosira sp., Cryptomonas sp. and Anabaena spiroides biomass decomposition. It is possible to infer that some species release more $\mathrm{H}$ protons than others. In addition, the decomposition releases $\mathrm{CO}_{2}$ as end product, thus producing carbonic acid in aqueous solutions. The acidification can cause a change in the microbial community. The acidification tendency occurred probably by the low quantities of humic substances formed due to the algae mineralization. In addition, buffer capacity of humic substances is mainly formed by polyphenols (Stevenson, 1982); the lack of these compounds in phytoplankton cells does not promote an effi-

Table 2. Maximum oxygen consumption $\left(\mathrm{OC}_{\max }\right)$ reported in the literature for algae.

\begin{tabular}{lcl}
\hline \multicolumn{1}{c}{ Species } & OC $_{\text {max }}\left(\mathbf{m g . g ~ \mathbf { C } ^ { - 1 } )}\right.$ & \multicolumn{1}{c}{ Citation } \\
\hline Staurastrum iversenni $-18^{\circ} \mathrm{C}$ & 124 & Pacobahyba (2002) \\
Staurastrum iversenni $-2{ }^{\circ} \mathrm{C}$ & 118 & Pacobahyba (2002) \\
Staurastrum iversenni $-25^{\circ} \mathrm{C}$ & 121 & Pacobahyba (2002) \\
Staurastrum iversenni $-27^{\circ} \mathrm{C}$ & 198 & Pacobahyba (2002) \\
Euglena proxima & 106 & Almazan and Boyd (1978) \\
Anabaena circinalis & 633 & Almazan and Boyd (1978) \\
Spirogyra sp. & 201 & Almazan and Boyd (1978) \\
Pithophora kewensis & 89 & Almazan and Boyd (1978) \\
Chara braunii & 116 & Almazan and Boyd (1978) \\
Cryptomonas sp. & 169 & This study \\
Microcystis aeruginosa & 68 & This study \\
Anabaena spiroides & 345 & This study \\
Thalasiosira sp. & 156 & This study \\
Aulacoseira granulata & 43 & This study \\
\hline
\end{tabular}


cient buffer system. The regular liberation of ions, represented by the EC values, can support phytoplankton and macrophyte growth, increasing the primary production in eutrophic systems through the regeneration of nitrogen and phosphorous (Andersen and Jensen, 1992).

This study demonstrates how the selected algae (the main species of local phytoplankton regarding to biomass) can affect, in a short time, the oxygen availability in the water column in Barra Bonita Reservoir, owing to the aerobic decay during a die-off event. It also indicates the possibility of the increase in electrical conductivity and $\mathrm{pH}$ values in the water column due mainly to the aerobic algae mineralization.

Acknowledgments - The authors thank Fundação de Amparo à Pesquisa do Estado de São Paulo (FAPESP proc. $n^{\circ}$ 1999/007766-0 e 2000/03122-0) and Coordenadoria de Aperfeiçoamento de Pessoal de Nível Superior (CAPES) for partial support of these assays.

\section{References}

ANDERSEN, FO. and JENSEN, HJ., 1992. Regeneration of inorganic. phosphorus and nitrogen from decomposition of seston in a freshwater sediment. Hydrobiologia, vol. 228, no. 1, p. $71-81$.

ALMAZAN, G. and BOYD, CE., 1978. Effects of nitrogen levels on rates of oxygen consumption during decay of aquatic plants. Aquatic Bot., vol. 5, p. 119-126.

BARBOSA, FAR., PADISÁK, J., ESPÍNDOLA, ELG., BORICS, G. and ROCHA, O., 1999. The cascading reservoir continuum concept (CRCC) and its application to the river Tietê-basin, São Paulo State, Brazil. In TUNDISI, JG. and STRAŠKRABA, M. (eds.) Theoretical reservoir ecology and its applications. Brazilian Academy of Science/International Institute of Ecology/Backhuys Publishers, Rio de Janeiro.

BARICA, J., 1974. Extreme fluctuations in water quality of eutrophic fish kill lakes: effect of sediment mixing. Water Res., vol. 8 , no. 11 , p. 881-888.

BIANCHINI JR., I., PERET., AM. and CUNHA-SANTINO, MB., 2006. A mesocosm study of aerobic mineralization of seven aquatic macrophytes. Aquatic Bot., vol. 85, no. 2, p. 163-167.

BROOK, AJ., 1981. The biology of desmids. Blackwell Scientific Publication, Oxford, 276 p.

BROUWER, PEM., 1996. Decomposition in situ of the sublittoral Antarctic macroalga Desmarestia anceps Montagne. Polar Biol., vol. 16, no. 2, p. 129-137.

CHARACKLIS, WG., 1990. Kinetics of microbial transformations. In CHARACKLIS, W., and MARSHALL, KC. (eds.). Biofilms. John Wiley and Sons, New York.

CHEN, W. and WANGERSKY, PJ., 1996. Production of dissolved organic carbon in phytoplankton cultures as measured by. High-temperature catalytic oxidation and ultraviolet photo-oxidation methods. J. Plankton Res., vol. 18, no. 7, p. 1201-1211.

CUNHA-SANTINO, MB. and BIANCHINI Jr., I., 2002. Humic substance ineralization from a tropical oxbow lake (São Paulo, Brazil). Hydrobiologia, vol. 468, no. 1-3, p. 34-44.
CUNHA-SANTINO, MB., BIANCHINI Jr., I. and SERRANO, LEF., 2002. Aerobic and anaerobic degradation of tannic acid on water samples from Monjolinho reservoir (São Carlos, SP Brazil). Braz. J. Biol., vol. 64, no. 2, p. 585-590.

CUNHA-SANTINO, MB. and BIANCHINI Jr., I., 2003a. Determination of the aeration coefficient for long-term BOD experiments. Acta Scient., vol. 25, no. 2, p. 253-256.

-, 2003b, Oxygen consumption during mineralization of organic compounds in water samples from a small sub-tropical reservoir (Brazil). Brazil. Arch. Biol. Technol., vol. 46, no. 4, p. 723-729.

DANIELS, RM., RICHARDSON, TL. and DUCKLOW, HW., 2006. Food web structure and biogeochemical process during oceanic phytoplankton blooms: an inverse model analysis. Deep Sea Res. II, vol. 53, no. 5-7, p. 532-554.

DELLAMANO-OLIVEIRA, MJ., VIEIRA, AAH. Dinâmica da comunidade fitoplanctônica do reservatório de Barra Bonita (SP, Brasil). (Submitted).

GORHAM, PR., MCLACHLAN, J., HAMMER, UT. and KIM, WK., 1964. Isolation and culture of toxic strains of Anabaena flos-aquae (Lingb.). Verh. Internat. Verein. Limnol., vol. 15, p. $796-804$.

GUILLARD, RRL. and LORENZEN, CJ., 1972. Yellow-green algae with chlorophyllid-c. J. Phycol., vol. 8, p. 10-14.

GUNNISON, D. and ALEXANDER, M., 1975. Resistance and susceptibility of algae to decomposition by natural microbial communities. Limnol. Oceanogr., vol. 20, no. 1, p. 64-70.

HARTEMINK, AE. and O'SULLIVAN, JN., 2001. Leaf litter decomposition of Piper aduncum, Gliricidia sepium and Imperata cylindrica in the humid lowlands of Papua New Guinea. Plant Soil, vol. 230, no. 1, p. 115-124.

HENZE, M., HARREMOËS, P., JANSEN, JC. and ARVIN, E., 1997. Wastewater Treatment- Biological and chemical processes, Springer-Verlag, Berlin, $383 \mathrm{p}$.

HENRY, R., HINO, K., GENTIL, JG. and TUNDISI, JG., 1985. Primary production and effects of enrichment with nitrate and phosphate on phytoplankton in the Barra Bonita reservoir (State of São Paulo, Brazil). Int. Revue Ges. Hydrobiol., vol. 70, no. 4, p. $561-573$.

LEE, HS. and LEE, JHW., 1995. Continuous monitoring of short term dissolved oxygen and algal dynamics, Water Res., vol. 29 , no. 12 , p. $2789-2796$.

OTSUKI, A. and HANYA, T., 1972a. Production of dissolved organic matter from dead green algal cells. I. Aerobic microbial decomposition. Limnol. Oceanogr., vol. 17, no. 2, p. 248-257.

-, 1972b. Production of dissolved organic matter from dead green algal cells. II. Anaerobic microbial decomposition. Limnol. Oceanogr., vol. 17, no. 2, p. 258-264.

PACOBAHYBA, LD., 2002. Decomposição de Straurastrum c.f. iversenii Nygaard var. americanum: efeitos da qualidade do recurso, da disponibilidade de oxigênio e da temperatura, $118 \mathrm{p}$. (Tese de Doutorado) - UFSCar/PPG-ERN, São Carlos.

PACOBAHYBA, LD., BIANCHINI Jr., I., VIEIRA, AAH. and CUNHA-SATINO, MB., 2004. The mineralization kinetics of Staurastrum iversenii Nygaard var. americanum. Acta Limnol. Brasil., vol. 16, no. 4, p. 391-400. 
PANHOTA, RS. and BIANCHINI Jr., I., 2003. Potential cycling of organic matter in a eutrophic reservoir (Barra Bonita - SP Brazil). Acta Limnol. Brasil., vol. 15, no. 2, p. 1-11.

PLATT, T. and IRWIN, B., 1973. Caloric content of phytoplankton. Limnol. Oceanogr., vol. 18, no. 2, p. 306-310.

PRESS WH., FLANNERY, BP., TEUKOLSKY, SA. and VETTERLING, WT., 1993. Numerical recipes in C: the art of scientific computing. Cambridge University Press, New York, $994 \mathrm{p}$.

STEVENSON, FJ., 1982. Humus Chemistry. Wiley, New York, $443 \mathrm{p}$.

STRAŠKRABA, M. and TUNDISI, JG., 2000. Diretrizes para o gerenciamento de lagos - Gerenciamento da qualidade da água de represas. ILEC/IIE, São Carlos, vol. 9, $280 \mathrm{p}$.

TUNDISI, JG. and MATSUMURA-TUNDISI, T., 1990. Limnology and eutrophication of Barra Bonita Reservoir, S. Paulo State, Southern Brazil. Arch. Hydrobiol. Beih. (Ergebn. Limnol.), vol. 33, p. 661-676.

VIEIRA, AAH., 1977. Métodos de culturas de algas do plâncton marinho: estudos realizados nas regiões de Cananéia e Ubatuba. Bol. Inst. Oceanogr., vol. 26, p. 303-338.

WHITE, PA., KALFF, J. RASMUSSEN, JB. and GASOL, JM., 1991. The effect of temperature and algal biomass on bacterial production and specific growth rate in freshwater and marine habitats. Microbial Ecol., vol. 21, p. 99-118. 